\title{
PROFIL BERPIKIR RELASIONAL DALAM PEMECAHAN MASALAH MATEMATIKA SISWA SMA DITINJAU DARI GAYA KOGNITIF REFLEKTIF DAN IMPULSIF
}

\author{
Delviera Lukita Wardani \\ Pendidikan Matematika, FMIPA, Universitas Negeri Surabaya \\ delvierawardani16030174035@mhs.unesa.ac.id \\ Susanah \\ Pendidikan Matematika, FMIPA, Universitas Negeri Surabaya \\ susanah@unesa.ac.id
}

\begin{abstract}
Abstrak
Berpikir relasional menjadi salah satu masalah yang menarik dalam pendidikan matematika, hal ini dilatarbelakangi oleh kemampuan berpikir relasional siswa yang masih rendah. Ciri dari berpikir relasional yaitu siswa dapat berpikir dengan membangun hubungan dari berbagai objek/konteks yang terkait satu sama lain. Jenis penelitian ini menggunakan penelitian deskriptif kualitatif. Analisis data dalam penelitian ini dilakukan dengan reduksi data tes MFFT, wawancara, penyajian data dan penarikan kesimpulan. Subjek penelitian adalah dua siswi dengan kemampuan matematika sedang kelas XI SMA Negeri 15 Surabaya tahun ajaran 2020/2021 dengan materi rasio trigonometri. Dalam penelitian ini berpikir relasional siswa dapat dilihat dari bagaimana siswa membangun hubungan antara konsep dan informasi dalam mengidentifikasi masalah secara menyeluruh karena ada kemungkinan siswa menulis informasi secara lengkap atau tidak juga adanya perbedaan konsep yang digunakan. Siswa dengan gaya kognitif reflektif menggunakan bantuan gambar agar mempermudah menyelesaikan masalah, sedangkan siswa dengan gaya kognitif impulsif hanya menuliskan secara singkat mengenai apa saja yang diketahui pada soal. Salah satu siswa salah dalam menggunakan konsep sehingga merubah rencana penyelesaian. Keduanya sama-sama memeriksa kembali penyelesaian pada lembar jawaban masing-masing namun fokus pengecekan berbeda.
\end{abstract}

Kata Kunci: Berpikir relasional, Gaya kognitif, Impulsif, Reflektif, Pemecahan masalah

\begin{abstract}
Relational thinking is one of the interesting problems in mathematics education, this is motivated by the students low relational thinking ability. The characteristic of relational thinking is that students can think by building relationships from various objects/contexts that are related to each other. This type of research is qualitative descriptive research. The analysis of data in this study was done by reducing MFFT test data, interviews, data presentation, and withdrawal conclusions. The subject of this research is two students with moderate math abilities in grade XI of SMA Negeri 15 Surabaya in 2020/2021 year with trigonometric ratio material. In this research, the way students thinking with relationally can be seen from how students build the relationship of information in identifying problems as a whole because there is a possibility of students writing information in full or not also the different concepts they used. Subjects with a reflective cognitive style redrawed the problem to make it easier to solve the problem, while subjects with an impulsive cognitive style only wrote briefly what was known on the problem. One subject mistakenly used the settlement plan. Both of them checking back on the completion of each answer sheet, but the focus of checking is different.
\end{abstract}

Keywords: Relational thinking, Cognitive style, Impulsive, Reflective, Problem solving

\section{PENDAHULUAN}

Berpikir relasional merupakan komponen penting dalam proses berpikir, karena berpikir pada dasarnya merupakan proses mental dalam meletakkan hubungan- hubungan antara pengetahuan-pengetahuan yang dimiliki dalam menentukan suatu keputusan (Ahmadi \& Supriyono, 2013). Pemahaman relasional dapat dilihat dari kemampuan seseorang menggunakan suatu prosedur matematis yang hasilnya berasal dari menghubungkan berbagai konsep matematis yang relevan dalam menyelesaikan suatu masalah serta mengetahui mengapa prosedur tersebut dapat digunakan (Anggara, 2010). Siswa yang berusaha memahami secara relasional akan mencoba mengaitkan konsep baru dengan konsep-konsep yang dipahami untuk dikaitkan kemudian merefleksi keserupaan dan perbedaan antara konsep baru dengan pemahaman sebelumnya. Berpikir relasional termasuk kemampuan kita untuk memahami analogi antara objek atau peristiwa yang tampaknya berbeda dan untuk menerapkan aturan abstrak dalam situasi baru (Doumas \& Hummel, 2005). Pendapat tentang berpikir relasional juga dikemukakan oleh Molina, 
dkk. (2005) yaitu bahwa berpikir relasional sangat penting dalam matematika, karena ada banyak ide-ide dasar dalam matematika yang mengandung hubungan antara representasi yang berbeda dari angka dan operasi antara angka dan objek matematika. Menurut Carpenter, dkk. (dalam Baiduri, 2011:26) menyatakan bahwa,

"Students are said to think relationally if they (1) see the sign of 'equal' as a symbol of relation; (2) may focus on the structure of expression and (3) may be able to give rationally in using a strategy to solve number sentence problems involving operation". (Baiduri, 2011)

Dapat didefinisikan bahwa siswa dikatakan berpikir secara relasional jika siswa melihat ada tanda sama dengan sebagai simbol relasi, siswa dapat fokus pada struktur ekspresi, dan siswa dapat memberikan rasionaltias penggunaan strategi untuk menyelesaikan masalah kalimat bilangan yang melibatkan operasi. Carpenter dkk. (2003); Stephens (2006) (dalam Baiduri, 2011) menyatakan bahwa siswa dikatakan berpikir secara relasional jika siswa dapat memberikan rasionalitas penggunaan setiap strategi penyelesaian. Pendapat lain tentang berpikir relasional juga dikemukakan oleh Stephens dan Ribeiro (2012:377) yang menyatakan bahwa "However, the key role of equivalence in relational thinking needs to embrace the other key ideas discussed above", yang artinya berpikir relasional tidak hanya berpikir tentang kesetaraan melainkan lebih membahas tentang adanya ide atau pengetahuan yang saling terkait.. Mirna (2016) mengemukakan bahwa berpikir relasional adalah suatu cara berpikir yang berpusat pada relasi antar objek dan hal lain yang berkaitan. Seseorang dikatakan berpikir secara relasional jika seseorang tersebut mempertimbangkan segala sesuatu ke dalam hal interaksi objek dengan hal yang lain. Nimtrakul, dkk (2014) menyatakan bahwa berpikir relasional adalah proses membangun hubungan antara pengetahuan konseptual dan prosedural matematika siswa. Pendapat lain dikemukakan oleh Hejny, Jirotkova \& Kratichvilova (2006) yang menyatakan bahwa siswa dikatakan berpikir relasional jika membuat gambaran masalah secara keseluruhan. Dari beberapa pendapat yang telah diulas maka dalam penelitian ini yang dimaksud dari berpikir relasional adalah cara berpikir yang berpusat pada relasi antar objek dan konsep di dalam diri seseorang untuk mengetahui apa yang dikerjakan dan mengapa hal itu dilakukan, untuk memahami analogi antara objek atau peristiwa yang tampaknya berbeda dan untuk menerapkan aturan abstrak dalam situasi baru.

"Masalah atau problem adalah situasi yang mengandung kesulitan bagi seseorang dan mendorongnya untuk mencari solusi” (Dewanti, 2011:32). Pendapat lain dikemukakan oleh Moursund (2016:10) yang menyatakan bahwa "... a puzzle or problem might have more than one solution.". Yang artinya sebuah masalah bisa mempunyai lebih dari satu solusi. Karakteristik mendasar yang diperlukan selama proses pemecahan masalah adalah fleksibilitas (Widjajanti, 2011). Fleksibilitas seseorang dapat berkembang melalui perluasan pengetahuan yang diperlukan untuk memecahkan masalah-masalah yang tidak rutin. Siswono (2008) menjelaskan ciri-ciri suatu masalah sebagai berikut.

a. Individu menyadari atau mengenali suatu situasi (pertanyaan-pertanyaan) yang dihadapi. Hal ini menjelaskan bahwa individu memiliki pengetahuan awal/pengetahuan prasyarat.

b. Individu menyadari bahwa situasi tersebut memerlukan tindakan/aksi. Hal ini menjelaskan bahwa masalah tersebut menantang untuk diselesaikan.

c. Langkah pemecahan suatu masalah tidak harus jelas atau mudah ditangkap orang lain. Maksudnya, individu tersebut sudah mengetahui bagaimana menyelesaikan suatu masalah meskipun langkah pemecahan masalah tersebut belum terlihat jelas. (Siswono, 2008).

Masalah bisa diartikan sebagai suatu situasi atau pertanyaan yang diperoleh seseorang secara individu atau kelompok ketika mereka tidak memiliki aturan, algoritma atau prosedur tertentu yang digunakan untuk mendapatkan solusi dari suatu masalah tersebut. Sesuai dengan tujuan yang ingin dicapai melalui pembelajaran matematika pada Kurikulum 2013 yang tercantum dalam Peraturan Menteri Pendidikan Nasional Republik Indonesia No. 58 tahun 2014, pemecahan masalah terletak pada urutan pertama yang menunjukkan pentingnya kemampuan pemecahan masalah yang harus dimiliki siswa. Menurut Shadiq (2003), suatu pertanyaan dapat menjadi masalah jika menunjukkan adanya tantangan dalam pertanyaan tersebut, tidak dapat dipecahkan oleh suatu prosedur rutin. Berdasarkan uraian diatas maka dalam penelitian ini masalah adalah suatu situasi atau pertanyaan yang diperoleh seseorang saat mereka tidak memiliki aturan atau prosedur tertentu yang digunakan untuk menemukan solusi dari masalah tersebut.

Berdasarkan pendapat dari Polya (2004) bahwa ada 4 fase pemecahan masalah yaitu: 1) memahami masalahnya, 2) melihat bagaimana berbagai hal terhubung dan hal yang tidak diketahui dihubungkan dengan data, untuk mendapatkan ide dari solusi dan rencana, 3) melaksanakan rencana dan, 4) melihat kembali solusi yang sudah selesai, ditinjau dan diskusikan. Untuk memecahkan masalah perlu proses berpikir dan kemampuan berpikir dapat dilatih menggunakan pemecahan masalah secara umum khususnya masalah matematika. Pemecahan masalah penting dalam pembelajaran matematika karena dengan pemecahan masalah tersebut siswa dapat memiliki kemampuan dalam cara berpikir. Ketika siswa dihadapkan pada suatu masalah atau soal matematika dan memecahkannya, akan terjadi kegiatan mental dalam 
dirinya yaitu berpikir. Hal ini dapat dilakukan dengan meminta siswa untuk menceritakan ide-ide dalam pikirannya ketika memecahkan masalah tersebut. Prosedur penyelesaian masalah berpikir relasional memiliki karakteristik 1) membuat konsep masalah secara keseluruhan; 2) menganalisis untuk menemukan struktur inti masalah; 3) mencari elemen kunci atau relasi dalam masalah seperti relasi unsur-unsur yang diberikan dan tidak diketahui; dan 4) mengonstruksi strategi penyelesaian setelah elemen kunci atau relasi kunci ditemukan (Hejny, Jirotkova, \& Kratochvilova, 2006). Bahri, dkk (2019:39) mengatakan bahwa:

"The main difference between relational thinking and not relational thinking is that those who do not think relationally are based on activating some procedures in their minds after identifying problems, while students think rationally, students create a picture problems in his mind as a whole, analyzing to find the core structure, and looking for some important elements or relations to build a settlement strategy." (Bahri dkk., 2019:39)

Dari penjelasan tersebut dapat diartikan bahwa letak perbedaan antara berpikir relasional dan yang bukan berpikir secara relasional adalah pengaktifan prosedur dalam pikiran seseorang untuk mengidentifikasikan suatu masalah. Siswa yang berpikir secara relasional akan menciptakan suatu gambaran masalah secara keseluruhan, menganalisis masalah tersebut dan menemukan struktur intinya, kemudian mencari hubungan penting untuk membangun strategi penyelesaian.

Menurut Tafrilyanto (2016) bahwa seseorang yang berpikir secara relasional pada saat memecahkan suatu masalah akan melakukan hal-hal seperti; 1) Menciptakan gambaran masalah dalam pikirannya secara keseluruhan, 2) Menganalisis untuk menemukan struktur dalam permasalahan, 3) Mencari beberapa elemen penting atau relasi untuk membangun sebuah strategi penyelesaian. Setelah memahami, siswa akan membuat rencana dan dalam proses perencanaan mungkin akan menemukan sesuatu yang dibutuhkan untuk memahami masalah lebih baik lagi. Setelah rencana terbentuk, siswa melaksanakan rencana tersebut yang akan diperoleh solusi atau juga tidak. Jika tidak diperoleh solusi maka siswa kembali membuat rencana baru atau kembali ke tahap memahami masalah (Kafiar dkk, 2015). Dalam aktivitas pemecahan masalah, setiap inividu memiliki karakteristik yang berbeda-beda pada saat menyelesaikan masalah.

Seseorang yang mampu menyusun kemudian mengolah informasi dari pengalaman sebelumnya dikenal dengan gaya kognitif. Gaya kognitif banyak yang telah ditemukan para ahli, salah satunya adalah gaya kognitif yang didasarkan oleh perbedaan konseptual yaitu perbedaan gaya kognitif berdasarkan waktu yang digunakan untuk merespon stimulus. Gaya kognitif ini dibagi menjadi gaya kognitif reflektif dan gaya kognitif impulsif. Siswa memiliki gaya kognitif impulsif mengambil keputusan dengan cepat tanpa memikirkannya secara mendalam terlebih dahulu. Sebaliknya, siswa yang memiliki gaya kognitif reflektif lebih mempertimbangkan bermacam alternatif sebelum mengambil keputusan dalam situasi yang mempunyai penyelesaian tidak mudah (Nasution, 2008). Warli (2010) mengatakan bahwa anak yang bergaya kognitif reflektif mempunyai kreativitas pemecahan masalah yang lebih baik daripada anak yang berdaya kognitif impulsif, ini menandakan bahwa akan berbeda pula proses pemecahan masalah yang dilakukan oleh anak bergaya kognitif reflektif dan impulsif. Gaya kognitif siswa dapat diukur melalui Matching Familiar Figures Test (MFFT) yang dikemukakan oleh Warli (2010). Tes MFFT ini diberikan kepada siswa untuk mengetahui empat kategori gaya kognitif siswa, yaitu gaya kognitif reflektif, impulsif, fast accurate dan slow innacurate. Namun pada penelitian ini hanya diambil dua ketgori gaya kognitif siswa melalui Tes MFFT yaitu gaya berpikir reflektif dan impulsif. Berdasarkan pendapat di atas tentang gaya kognitif reflektif dan impulsif, keduanya mempunyai peran penting dalam pemecahan masalah. Hal ini yang memungkinkan seseorang yang mempunyai gaya kognitif berbeda akan mempunyai profil pemecahan masalah yang juga berbeda.

Cara berpikir secara relasional sebelumnya dibahas dalam penelitian yang dilakukan oleh Tafrilyanto (2016), A. Tatak \& Andy (2016) dan Susan dkk. (2011). Dalam penelitian yang dilakukan oleh Tafrilyanto (2016), siswa berpikir relasional dalam memecahkan masalah yang ditinjau dari gaya kognitif field dependent, dimana hanya diperoleh satu subjek yaitu siswa yang mempunyai gaya kognitif field dependent, untuk soal pemecahan masalahnya menggunakan materi SPLTV. Berbeda dengan penelitian yang dilakukan oleh A. Tatak dan Andy (2016), soal yang digunakan dalam penelitiannya menggunakan soal kontekstual materi fungsi linear. Sedangkan penelitian yang dilakukan oleh Susan dkk. (2011), subjeknya menggunakan siswa SD dengan materi aljabar. Namun, penelitian sebelumnya belum mengkaji tentang profil berpikir relasional dalam pemecahan masalah matematika siswa SMA ditinjau dari gaya kognitif reflektif dan impulsif. Berdasarkan hal tersebut, maka dalam penelitian ini akan menjelaskan tentang profil berpikir relasional dalam pemecahan masalah matematika siswa SMA ditinjau dari gaya kognitif reflektif dan impulsif. Adapun indikator berpikir relsional dalam memecahkan masalah matematika penelitian ini disajikan pada tabel berikut.

Tabel 1. Indikator berpikir relasional dalam memecahkan masalah (diadaptasi dari Baiduri, 2011)

1. Membaca / memahami masalah 


\begin{tabular}{|c|c|}
\hline $\begin{array}{c}\text { Kegiatan Berpikir } \\
\text { Relasional }\end{array}$ & Indikator \\
\hline $\begin{array}{l}\text { a. Membangun relasi } \\
\text { berdasarkan informasi } \\
\text { dalam suatu } \\
\text { permasalahan berdasar } \\
\text { pengetahuan } \\
\text { sebelumnya } \\
\text { b. Membangun/menciptak } \\
\text { an gambaran masalah } \\
\text { atau operasi dalam } \\
\text { pikirannya yang sesuai }\end{array}$ & $\begin{array}{l}\text { a. Membangun relasi } \\
\text { setiap unsur-unsur } \\
\text { bersesuaian pada } \\
\text { saat memahami } \\
\text { masalah } \\
\text { b. Menciptakan } \\
\text { gambaran relasi } \\
\text { setiap unsur-unsur } \\
\text { bersesuaian pada } \\
\text { saat memahami } \\
\text { masalah atau } \\
\text { operasi dalam } \\
\text { pikirannya yang } \\
\text { sesuai }\end{array}$ \\
\hline
\end{tabular}

2. Membuat rencana/memilih strategi

a. Membangun/ a. Membangun/

menganalisis relasi menganalisis relasi dengan menggunakan struktur serta menemukan strategi dalam memecahkan masalah

b. Membangun relasi berdasarkan informasi dalam suatu permasalahan berdasar pengetahuan sebelumnya

\section{Melaksanakan rencana}

a. Membangun/ menganalisis relasi dengan menggunakan struktur serta menemukan strategi dalam memecahkan masalah

b. Membangun relasi berdasarkan informasi dalam suatu permasalahan berdasar pengetahuan sebelumnya strategi pemecahan a. Membangun/

menganalisis relasi struktur operasi pada saat melaksanakan masalah

b. Membangun relasi berdasarkan informasi yang terdapat dalam suatu permasalahan berdasarkan pengetahuan sebelumnya pada saat melaksanakan rencana

4. Memeriksa kembali

\begin{tabular}{|c|c|}
\hline $\begin{array}{l}\text { a. Menganalisis } \\
\text { penggunaan struktur } \\
\text { operasi pada saat } \\
\text { memeriksa kembali }\end{array}$ & $\begin{array}{l}\text { Menganalisis } \\
\text { penggunaan struktur } \\
\text { operasi pada saat } \\
\text { memeriksa kembali }\end{array}$ \\
\hline
\end{tabular}

Berdasarkan uraian diatas, tujuan dari penulisan artikel ini untuk mengetahui bagaimana cara berpikir relasional siswa terhadap pemecahan masalah yang ditinjau dari gaya kognitif reflektif dan impulsif.

\section{METODE}

Tujuan penelitan ini untuk mendeskripsikan profil berpikir relasional siswa terhadap pemecahan masalah matematika ditinjau dari gaya kognitif reflektif dan impulsif, maka pendekatan yang digunakan dalam penelitian ini adalah kualitatif. Jenis penelitian ini adalah penelitian deskriptif kualitatif. Subjek penelitian diambil dari siswa kelas XI SMA Negeri 15 Surabaya sebanyak 34 siswa karena siswa kelas XI SMA telah mendapat pengetahuan tentang kesebangunan, Pythagoras, dan rasio trigonometri. Instrumen yang digunakan sebelumnya melalui tahapan validasi, jika instrumen yang dibuat sudah valid maka bisa dibuat tes pengajuan masalah. Instrumen yang digunakan dalam penelitian ini adalah tes Matching Familiar Figures Test (MFFT) yang dikemukakan oleh Warli (2010), Tes Pemacahan Masalah Matematika (TPMM) dan pedoman wawancara.

Teknik pengumpulan data tes MFFT untuk mengkategorikan siswa dengan gaya kogitif reflektif, kognitif impulsif. Setelah mendapat 1 (satu) siswa dengan gaya kognitif reflektif dan 1 (satu) siswa dengan gaya kognitif impulsif, kedua siswa diberi Tes Pemecahan Masalah (TPM) untuk mengetahui cara siswa dalam memecahkan soal masalah. Selanjutnya peneliti melakukan wawancara terkait dengan jawaban TPM masing-masing subjek. Wawancara ini digunakan untuk mengungkap atau memperoleh gambaran tentang permasalahan yang dihadapi oleh siswa dalam berpikir relasional untuk menyelesaikan masalah, peneliti berusaha melakukan pemeriksaan secara teliti terhadap subjek atau siswa mengenai apa yang dilakukan, diucapkan, dan yang dipikirkan siswa pada saat menghadapi dan menyelesaikan soal cerita.

\section{HASIL DAN PEMBAHASAN}

Setelah pemilihan subjek dilakukan, peneliti memberi lembar tes pemecahan masalah matematika kepada 2 subjek penelitian. Hasil tes pemecahan masalah matematika siswa dengan gaya kognitif reflektif dan gaya kognitif impulsif dijabarkan sebagai berikut.

\section{A. Hasil Penelitian}
1. Hasil dan Analisis Data Profil Berpikir Relasional dalam Pemecahan Masalah Matematika siswa SMA ditinjau dari Gaya




\section{Kognitif Reflektif}

Hasil dari soal pemecahan masalah dari subjek dengan gaya kognitif reflektif (SR) sebagai berikut.

\section{a. Tahap Memahami Masalah}

Berikut transkrip wawancara dengan subjek SR terkait dengan tahap memahami masalah.

P-02 : Tolong jelaskan informasi yang kamu dapat saat memahami soal

SR-02: Di soal itu saya lihat ada segitiga sama sisi yang besar, di dalamnya ada lingkaran, di dalam lingkaran ada segitiga samasisi lagi yang lebih kecil

SR-03 : Lalu disuruh menghitung rasio dari area dua segitiga, kemudian menggambar lingkaran kedua di dalam segitiga kecil. Dan disuruh menentukan perbandingan luas dua lingkaran,

SR-05 : Jadi saya baca-baca buku dulu, cari materinya itu tentang apa. Menggunakan rumus apa gitu. Yang saya tangkap dari soal ini menggunakan rumus rasio trigonometri dan kesebangunan.

Berdasarkan hasil dari lembar jawaban siswa dapat dinyatakan bahwa dalam memahami masalah SR mengidentifikasi informasi pada soal menggunakan bantuan berupa gambar. Kemudian mencari rumus yang akan digunakan untuk menyelesaikan soal. Dalam tahap memahami masalah, SR dapat membangun relasi setiap unsur-unsur yang bersesuaian. Berikut juga ditampilkan transkrip wawancara subjek SI dalam tahap memeriksa kembali.

\section{b. Membuat Rencana}

Berikut ditampilkan transkrip wawancara dengan subjek SR terkait dengan tahap merencanakan masalah.

SR07: Jadi seperti waktu nyari perbandingan sisi depan dari segitiga istimewa itu bisa menggunakan rasio trigonometri. Kalau cari salah satu sisi atau panjang, itu bisa menggunakan rumus Pythagoras. Kalau yang kesebangunan itu untuk mencari rasio dua segitiga tadi dan perbandingan luas dari lingkaran.

Berdasarkan lembar penyelesaian yang dianalisis dengan hasil wawancara dapat dinyatakan bahwa dalam tahap membuat rencana penyelesaian masalah SR menemukan ide awal menggunakan rasio trigonometri dan kesebangunan. Selanjutnya dari ide awal itu juga bisa digunakan untuk mencari perbandingan sisi depan sudut pada segitiga. Untuk nilai yang belum diketahui, SR menggunakan variabel untuk memberi tanda pada gambar kemudian subjek mencari perbandingan sudut sisi depan. Setelah itu subjek menggambar garis bagi agar memudahkan pengerjaan. Subjek dapat menyebutkan konsep apa saja yang diperlukan untuk menyelesaikan soal.
Dalam tahap membuat rencana, SR sesuai dengan indikator berpikir relasional saat tahap membuat rencana yaitu subjek dapat membangun atau menganalisis relasi secara terstruktur dalam memilih strategi penyelesaian, serta subjek dapat menganalisis aturan untuk menghasilkan suatu rencana pada saat memilih strategi. Subjek diminta untuk menjelaskan informasi yang didapat dari pengetahuan sebelumnya. Kemudian subjek menjelaskan mengenai materi yang berkaitan dengan soal yang didapat untuk membuat rencana penyelesaian masalah.

\section{c. Melaksanakan Rencana}

Berikut transkrip wawancara dengan subjek SR terkait dengan tahap melaksanakan rencana penyelesaian masalah.

P-08: Tolong jelaskan cara-cara yang kamu gunakan agar bisa menyelesaikan soal.

SR-08: Saya menggambar dulu, setelah itu saya mencari Panjang atau garis bagi. Sehingga nanti terbentuk segitiga siku-siku. Itu nanti cari perbandingan sisi depan menggunakan perbandingan $30: 60: 90$

Saat ditanya perbandingan yang didapat dengan menggunakan perbandingan sisi depan, subjek menjawab sesuai dengan rumus yang ada. Kemudian subjek menjelaskan Langkah-langkah yang digunakan dalam tahap melaksanakan rencana.

SR-010: Saya dapatnya $1: \sqrt{3} x: 2$. Itu saya dapat dari rumus.

SR-011: Pertama saya gambar dulu supaya mudah saya pahami. Kemudian pertama saya nyari perbandingan sisi tadi, setelah ketemu kita bisa mencari sisi yang belum diketahui.

P013: Bagaimana cara penyelesaian soalnya Ryn?

SR013: $\frac{3 x}{\sqrt{3}} \cdot \frac{\sqrt{3}}{\sqrt{3}}$

Setelah itu mencari sisi $A P, A P=6 x$.

Saat ditanya mengenai hasil yang didapat, subjek dapat menjawabnya dengan benar.

SR014: Dari $\frac{1}{3}$ panjang CP. $C P=3 O P$

Jadi $3.2 x=6 x$, dengan Panjang $O P=2 x$

Kemudian dari segitiga CPB. Disini $B C=4 \sqrt{ } 3 x$, itu dari $\frac{6 x}{\sqrt{3}} \cdot 2=\frac{12 x}{\sqrt{3}} \cdot \frac{\sqrt{3}}{\sqrt{3}}$

Panjang $P B=4 \sqrt{3} x$

Setelah itu menggunakan kesebangunan dari 2 segitiga tadi.

$L \triangle A B C: L \triangle D E F$

$1 / 2 A B . C Q: 1 / 2 D E . F P$

$4: 1$

P015: Jadi jawabannya untuk yang a?

SR015: $4: 1$

SR016: Setelah itu mencari perbandingan untuk lingkaran. Lingkaran 1 : Lingkaran 2

L1 : L2 


$$
\begin{aligned}
& (2 x)^{2}: x^{2} \\
& 4 x^{2}: x^{2} \\
& 4: 1
\end{aligned}
$$

Saat ditanya mengenai simbol yang dibuat, subjek dapat menjawabnya dengan baik tanpa mengalami perubahan rencana dari rencana awal yang dibuat.

SR-017: 2x itu jari-jari lingkaran yang besar

\section{P-018: Kalau untuk $x$ ?}

SR-018 : Itu jari-jari lingkaran kecil atau lingkaran kedua.

Berdasarkan lembar jawaban yang dianalisis dapat diungkap bahwa SR mengerjakan sesuai dengan rencana yang telah dibuat dan tidak menemukan kendala dalam pengerjaan. SR kembali menggunakan bantuan gambar agar mempermudah membayangkan soal yang dikerjakan dan mempermudah dalam penyelesaian soal. Dalam tahap melaksanakan rencana, SR sesuai dengan indikator berpikir relasional saat tahap melaksanakan rencana yaitu subjek dapat menganalisis relasi struktur operasi dan membangun relasi berdasarkan informasi yang terdapat dalam suatu permasalahan berdasarkan pengetahuan sebelumnya. Subjek diminta menjelaskan cara yang digunakan agar dapat menyelesaikan soal. Kemudian subjek menjelaskan tentang materi yang digunakan serta menjelaskan tahap- tahap penyelesaian masalah.

\section{d. Memeriksa Kembali}

Berikut ditampilkan transkrip wawancara dengan subjek SR terkait dengan tahap memeriksa kembali.

P-019: Kemudian tolong jelaskan rumus yang kamu pakai dan berkaitan dengan yang kamu pelajari itu apa saja?

SR-019: Kalau yang perbandingan sisi sisi segitiga khusus itu pakai sudut-sudut 30:60:90, supaya didapat jari-jari lingkaran. Untuk rasio itu menggunakan kesebangunan, untuk mencari salah satu sisi, pakai rumus segitiga khusus. Atau bisa juga pakai Pythagoras

Subjek ditanya apakah subjek melakukan pengecekan kembali setelah menjawab soal, subjek menjawab bahwa Ia melakukan pengecekan kembali pada rumus- rumus yang digunakan, apakah rumus tersebut sudah sesuai atau belum. Kemudian subjek menjelaskan langkah-langkah pengecekan jawaban dalam tahap memeriksa kembali.

SR-021: Saya lihat rumusnya itu sudah benar atau belum, tadi saya memisalkan beberapa, kemudian saya cek lagi di rumusnya sudah benar atau belum saya memasukkannya.

Saat ditanya apa tujuan subjek menggambar pada setiap Langkah yang dikerjakan, SR menjawab agar lebih mudah untuk menyelesaikan soal tersebut. Hal ini ditunjukkan dari wawancara yang dilakukan dengan SR.
SR-022: Itu untuk mempermudah mengerjakan, jadi saya bisa membayangkan cara penyelesaiannya nanti seperti apa.

Berdasarkan lembar jawaban yang dianalisis dapat terungkap bahwa dalam tahap memeriksa kembali SR melakukan pengecekan terhadap rumus yang dimasukkan serta mengecek secara keseluruhan penyelesaian dalam lembar jawaban. SR menyimpulkan jawaban yang telah diperoleh dengan menuliskannya pada akhir penyelesaian. Dalam tahap memeriksa kembali, SR sesuai dengan indikator berpikir relasional saat tahap memeriksa kembali yaitu subjek dapat menganalisis penggunaan struktur operasi. Pada saat subjek diminta menjelaskan tentang rumus yang digunakan untuk menyelesaikan masalah, subjek mengaitkan dengan pengetahuan yang sudah didapat sebelumnya.

\section{Hasil Analisis Data Profil Berpikir Relasional dalam Pemecahan Masalah Matematika Siswa SMA ditinjau dari Gaya Kognitif Impulsif}

Hasil dari soal pemecahan masalah dari subjek dengan gaya kognitif impulsif (KI) sebagai berikut.

\section{a. Memahami Masalah}

Berikut ditampilkan transkrip wawancara dengan subjek SI terkait dengan tahap memahami masalah.

SI-02: Dibaca dulu terus mencari informasi di buku
biar tau itu materi apa dan cara
penyelesaiannya

SI-03: Dalam soal ini ada segitiga besar, di dalamnya ada lingkaran dan di dalamnya lagi ada segitiga kecil. Disitu disuruh untuk mencari rasio dua segitiga dan perbandingan luas dua lingkaran.

SI-07: Saya mencari rumus dari buku. Kemudian menentukan kira-kira ini materi apa.

Berdasarkan lembar jawaban yang dianalisis terungkap bahwa dalam tahap memahami masalah SI mengidentifikasi informasi dengan menuliskan yang diketahui dan dituliskan dengan benar. SI menggambarkan ulang gambar pada soal dan diberi garis bagi di dalam segitiga untuk lebih memahami soal dan mempermudah penyelesaian selanjutnya. Dalam tahap memahami masalah, SI sesuai dengan indikator berpikir relasional dalam memahami masalah yaitu subjek dapat membangun relasi setiap unsur-unsur yang bersesuaian subjek dapat menganalisis penggunaan struktur operasi. Saat ditanya bagaimana cara subjek memahami masalah yang ada pada soal, subjek mencari pada buku mengenai hal-hal yang berkaitan kemudian menjelaskan tentang informasi apa saja yang diketahui pada soal. Hal ini dibuktikan dalam wawancara yang dilakukan pada SI.

\section{b. Membuat Rencana}


Berikut juga ditampilkan transkrip wawancara subjek SI dalam tahap membuat rencana.

SI-012: Yang rumus perbandingan sisi segitiga itu menggunakan perbandingan sudut sedangkan yang rasio itu menggunakan kesebangunan.

Berdasarkan lembar jawaban yang dianalisis SI menemukan ide awal menghitung sisi depan sudut segitiga menggunakan teorema Pythagoras, membandingkan luas segitiga kecil dan besar, kemudian membandingkan luas 2 lingkaran. Dalam tahap membuat rencana, SI sesuai dengan indikator berpikir relasional saat tahap membuat rencana yaitu subjek dapat membangun atau menganalisis relasi secara terstruktur dalam memilih strategi penyelesaian, serta subjek dapat menganalisis aturan untuk menghasilkan suatu rencana pada saat memilih strategi. Saat subjek diminta menjelaskan apakah ada hubungannya materi yang sudah pernah didapat dengan soal yang diberikan, subjek menjawab ada, kemudian menjelaskan materi apa saja yang berkaitan dengan soal

\section{c. Melaksanakan Rencana}

SI-013 : Pertama saya mencari rumus perbandingan sisi segitiga dulu

SI-014 : $1: \sqrt{ } 3: 2$. Ini pernah saya dapat di internet dulu atau buku saya lupa.

SI-015: $30: 60: 90$ yaitu $1: \sqrt{ } 3: 2 \mathrm{CO}: O P=2: 1$

$O P=$ jari-jari lingkaran besar $=D O$ Luas lingkaran besar yaitu $\pi r 2$

Luas segitiganya $1 / 2$ at Luas lingkaran kecil $\pi 2 \times 2$ Luas segitiga DEF itu $1 / 2$

SI016: Pertama kita mencari sisinya dulu, $2 \sqrt{3} x, Q E=$ $\sqrt{3} x$

Kita masukkan kedalam perbandingannya.

Itu masih segitiga kecil, untuk segitiga besar BC $=4 \sqrt{3} x$

Sisi $P B=2 \sqrt{3} x$

Setelah itu dimasukkan ke perbandingan

$L \triangle C A B: L \triangle F D E$

$1 / 2 A B . C B: 1 / 2 D E . F Q$

$4 \sqrt{3} x .6 x: 2 \sqrt{3} x 3 x$

$24 \sqrt{3} x: 6 \sqrt{3} x$

$4: 1$

SI-017: Tinggal masukkan rumus yaitu

$\pi r^{2}: \pi r^{2}$

$(2 x)^{2}: x^{2}$

Menghasilkan

$4: 1$

Saat ditanya mengenai simbol yang dibuat, subjek dapat menjawab dengan baik.
SI-018: Dari jari-jari lingkaran 1. Yaitu CA, dari segitiga $C A B$

P-041: Kalau $x$ ?

SI-019: Kalau x dari jari-jari lingkaran kedua yaitu DE dari segitiga $F D E$

Berdasarkan lembar jawaban yang dianalisis terungkap bahwa SI mengerjakan sesuai dengan yang telah direncanakan namun mengalami kesalahan dalam mencari panjang sisi segitiga. SI mengubah rencana yang akan digunakan menggunakan materi perbandingan sisi pada segitiga khusus 30 : 60 : 90 dan rumus trigonometri.

Dalam tahap melaksanakan rencana, SI sesuai dengan indikator berpikir relasional saat tahap melaksanakan rencana yaitu subjek dapat menganalisis relasi struktur operasi dan membangun relasi berdasarkan informasi yang terdapat dalam suatu permasalahan berdasarkan pengetahuan sebelumnya. Selain menampilkan kutipan jawaban dari SI juga ditampilkan transkrip wawancara dengan subjek SI terkait dengan tahap melaksanakan rencana. Saat ditanya mengenai bagaimana strategi yang disusun agar subjek bisa menyelesaikan soal, SI menjawab Ia menggunakan rumus perbandingan sisi segitiga.

Saat diminta untuk menjelaskan tahapan Langkahlangkahnya, subjek yang mulanya menggunakan Pythagoras pada awal langkah kemudian diganti karena merasa kesulitan. Subjek kembali menggunakan perbandingan sisi segitiga khusus, kemudian menjelaskan langkah-langkah penyelesaian yang dilakukan. Untuk menyelesaikan poin $b$, subjek memasukkan rumus perbandingan luas lingkaran.

\section{d. Memeriksa Kembali}

Berikut ditampilkan transkrip wawancara subjek SI dalam tahap memeriksa kembali.

SI-020: Perbandingan sisi segitiga khusus itu dipakai sudut-sudut 30 : 60 : 90, supaya diketahui jarijari lingkaran. Kalau kesebangunan itu digunakan untuk mencari rasio. Untuk mencari salah satu sisi itu menggunakan rumus Pythagoras. 0

Subjek melakukan pengecekan kembali pada hasil pengoperasian yang dilakukan.

SI022 : Kalau pengecekannya cuman kayak yang hasil dari perkaliannya sama pembagiannya itu sudah betul atau belum.

Berdasarkan lembar jawaban dan data wawancara yang dianalisis terungkap bahwa SI memeriksa kembali tahaptahap penyelesaiannya namun SI hanya berfokus pada hasil pengoperasian, kemudian membuat kesimpulan atas jawaban yang sudah diperoleh. SI memberi kesimpulan singkat tentang jawaban yang telah diperoleh pada akhir penyelesaian. Dalam tahap memeriksa kembali, SI sesuai 
dengan indikator berpikir relasional saat tahap memeriksa kembali yaitu subjek dapat menganalisis penggunaan struktur operasi Subjek diminta untuk menjelaskan mengenai rumus yang berkaitan dengan soal, subjek juga melakukan pengecekan kembali pada soal yang telah diselesaikan.

\section{B. Pembahasan}

Berdasarkan data yang sudah dianalisis dan diuraikan maka pembahasan mengenai berpikir relasional dalam pemecahan masalah matematika siswa SMA ditinjau dari gaya kognitif reflektif dan impulsif dijabarkan sebagai berikut.

\section{Profil Berpikir Relasional Siswa dengan Gaya Kognitif Reflektif}

Di dalam memahami masalah siswa dengan gaya kognitif reflektif menemukan unsur-unsur yang penting kemudian ditulis secara lengkap dan jelas mengenai informasi dalam soal. Setelah itu berdasarkan hasil wawancara siswa dengan gaya kognitif reflektif mengkorelasikan keterkaitan tentang masalah secara keseluruhan dengan informasi yang didapat. Sesuai dengan indikator berpikir relasional saat tahap memahami masalah, siswa dapat membangun relasi setiap unsur-unsur yang bersesuaian.

Siswa juga memahami masalah dengan bantuan gambar untuk mempermudah penyelesaian soal. Dengan bantuan gambar terebut, siswa tidak mengalami kesulitas saat melaksanakan rencana. Hal ini sejalan dengan hasil penelitian yang dilakukan oleh Warli (2010) bahwa siswa dengan gaya kognitif reflektif mempunyai kreativitas lebih baik daripada siswa dengan gaya kognitif impulsif. Siswa dengan gaya kognitif reflektif dalam penyelesaian masalah membuat penyelesaian yang variatif dan dapat dipahami oleh orang lain.

Saat merencanakan masalah, siswa dengan gaya kognitif reflektif mengaitkan informasi pada soal dengan pengetahuan yang sudah dimiliki. Perencanannya itu digunakan hingga tahap akhir pemecahan masalah yaitu tahap memeriksa kembali tanpa perubahan rencata. Sesuai dengan indikator berpikir relasional saat tahap membuat rencana, siswa dapat membangun/menganalisis relasi secara terstruktur dalam memilih strategi penyelesaian. Siswa dengan gaya kognitif reflektif juga dapat menganalisis aturan untuk menghasilkan suatu perencanaan pada saat memilih strategi dalam pemecahan masalah.

Dalam tahap melaksanakan rencana, siswa mampu menganalisis relasi struktur operasi dan membangun relasi berdasarkan informasi yang terdapat dalam suatu permasalahan berdasarkan pengetahuan sebelumnya. Hal ini sejalan dengan pendapat yang diutarakan Stephens \& Ribeiro (2012) bahwa siswa dapat mengemukakan bahwa berpikir relasional tidak hanya berpikir tentang kesetaraan melainkan lebih membahas tentang adanya ide atau pengetahuan yang saling terkait. Sesuai dengan indikator berpikir relasional saat tahap melaksanakan rencana siswa dapat menganalisis relasi struktur operasi dan membangun relasi berdasarkan informasi yang terdapat dalam suatu permasalahan berdasarkan pengetahuan sebelumnya. Dalam tahap ini siswa diminta untuk menjelaskan cara yang digunakan agar dapat menyelesaikan soal. Kemudian siswa menjelaskan tentang materi yang digunakan serta menjelaskan tahap- tahap penyelesaian masalah.

Berdasarkan hasil wawancara, siswa mempertimbangkan konsep yang akan digunakan untuk menyelesaikan masalah. Hal ini sejalan dengan pendapat Mirna (2016) bahwa berpikir relasional adalah suatu cara berfikir yang pusatnya ada pada relasi antar objek dan hal lain yang berkaitan, seseorang dikatakan berpikir secara relasional jika seseorang tersebut mempertimbangkan segala sesuatu dalam hal interaksi objek dengan hal yang lain. Siswa dapat menyimpulkan jawaban yang telah diperoleh dengan menuliskannya pada akhir penyelesaian. Dalam tahap memeriksa kembali, sesuai dengan indikator berpikir relasional saat tahap memeriksa kembali dan mengevaluasi keseluruhan jawaban yang telah dikerjakan. Mengaitkan kembali informasi yang didapat dalam soal dengan metode penyelesaian yang digunakan untuk mengetahui apakah sudah memenuhi jawaban yang diinginkan. Uraian tersebut sejalan dengan pendapat Carpenter dkk dan Stephens, A (dalam Baiduri, 2011) yang menyatakan bahwa siswa dikatakan berpikir relasional jika siswa dapat memberikan rasionalitas penggunaan setiap strategi penyelesaian.

\section{Profil Berpikir Relasional Siswa dengan Gaya Kognitif Impulsif}

Dalam tahap memahami masalah, siswa dengan gaya kognitif impulsif tidak tampak jelas apakah siswa sudah bisa dikatakan berpikir secara relasional atau tidak. Maka dilakukan proses wawancara untuk mengetahui hal tersebut. Berdasarkan hasil wawancara, siswa mampu menjelaskan secara detail mengenai informasi yang didapat pada soal. Hal ini sejalan dengan pendapat dari Hejny, Jirotkova \& Kratichvilova (2006) bahwa siswa dikatakan berpikir relasional jika membuat gambaran masalah secara keseluruhan. Berdasarkan hasil wawancara, siswa dengan gaya kognitif impulsif memberikan informasi lebih minim dan tidak detail. Namun siswa dapat membangun relasi setiap unsur yang bersesuaian saat memahami masalah.

Kegiatan berpikir relasional siswa dengan gaya kognitif impulsif terlihat dari hasil wawancara dan lembar jawaban soal saat siswa dapat erencanakan 
penyelesaian masalah dengan membangun keterkaitan antara informasi dan pengetahuan yang sudah didapatkan. Dalam tahap membuat rencana, siswa dapat membangun serta menganalisis aturan untuk menghasilkan suatu rencana dan menganalisis relasi secara terstrukur dalam memilih strategi penyelesaian. Hal ini sejalan dengan pendapat yang diutarakan Stephens \& Ribeiro (2012) bahwa siswa dapat mengemukakan bahwa berpikir relasional tidak hanya berpikir tentang kesetaraan melainkan lebih membahas tentang adanya ide atau pengetahuan yang saling terkait.

Saat melaksanakan rencana, siswa dengan gaya kognitif impulsif mengalami kesulitan menyelesaikan masalah, siswa pun kembali ke tahap merencanakan penyelesaian masalah kemudian mengganti rencananya. Dengan menggunakan rencana baru ini, siswa menemukan hasil hingga tahap akhir pemecahan masalah yaitu memeriksa kembali. Hal ini sejalan dengan pendapat Molina, Castro \& Ambrose (2005) yaitu banyak ide-ide dasar dalam matematika yang mengandung hubungan antara representasi yang berbeda dari angka dan operasi antara angka dan objek matematika. Suatu permasalahan jika tidak diphami secara teliti, maka nampaknya dapat diselesaikan dengan suatu konsep. Namun saat dicoba menyelesaikannya, mengalami kesalahan dalam analisa sehingga mengharuskan seseorang untuk merubah rencana penyelesaian masalahnya kembali. Hal inilah yang dialami oleh siswa dengan gaya kognitif impulsif, siswa mencoba menemukan ide-ide dasar dalam matematika yang lain agar dapat menemukan penyelesaian masalah.

Berdasarkan hasil wawancara, siswa memeriksa kembali dan mengevaluasi jawaban yang telah dikerjakan. Tetapi saat melakukan perencanaan yang telah dibuat, KI menemukan kesulitan dan mengubah metode yang akan digunakan selanjutnya. Dengan mengaitkan kembali informasi yang didapat dalam soal dengan pengetahuan yang dimiliki siswa, akhirnya ditemukan penyelesaian masalah kemudian siswa melakukan pengecekan yang digunakan untuk mengetahui apakah penyelesaian tersebut sudah memenuhi jawaban yang diinginkan. Uraian tersebut sejalan dengan pendapat dengan pendapat Carpenter dkk dan Stephens, A (dalam Baiduri, 2011) yang menyatakan bahwa siswa dikatakan berpikir relasional jika siswa dapat memberikan rasionalitas penggunaan setiap strategi penyelesaian.

Berdasarkan penjelasan di atas, terdapat perbedaan dan persamaan kegiatan berpikir relasional antara siswa gaya kognitif reflektif dan gaya kognitif impulsif. Berikut uraian perbedaan dan persamaan tersebut

\section{PENUTUP}

\section{Simpulan}

Berdasarkan hasil dan pembahasan yang telah diulas, cara berpikir relasional siswa SMA adalah sebagai berikut. Siswa yang memiliki gaya kognitif reflektif pada tahap memahami masalah menjelaskan tentang apa saja yang diketahui dan ditanya dalam soal serta bagaimana cara siswa memahami soal. Siswa menggunakan bantuan gambar pada setiap tahap pemecahan masalah agar memudahkan dalam penyelesaian soal, siswa menemukan hubungan antar konsep dengan permasalahan yang diberikan. Siswa juga dapat mengaitkan informasi yang didapat dari soal dengan pengetahuan yang sudah dimiliki. Rencana yang dibuat dilanjutkan ke tahap melaksanakan rencana, siswa tidak mengalami kesulitan dalam tahap ini hingga tahap akhir yaitu memeriksa kembali penyelesaian yang telah diperoleh, siswa memeriksa kembali terkait konsep yang digunakan. Siswa yang memiliki gaya kognitif impulsif dalam pemecahan masalah pada tahap memahami masalah hingga memeriksa kembali menggunakan cara berpikir relasional. Pada tahap memahami masalah belum tampak cara berpikir relasional siswa pada lembar tes pemecahan masalah, sehingga dilakukan pendalaman pada saat tes wawancara. Siswa hanya menuliskan informasi yang diketahui dalam soal secara detail tanpa menggunakan bantuan gambar dalam setiap tahap penyelesaian masalah. Saat melaksanakan rencana penyelesaian masalah, siswa mengalami kesulitan sehingga mengubah metode yang digunakan dan merencanakan penyelesaian kembali. Setelah menemukan hasil siswa memeriksa kembali penyelesaian yang telah diperoleh.

\section{Saran}

Berdasarkan simpulan hasil penelitian yang telah dilakukan peneliti mengenai profil berpikir relasional dalam pemecahan masalah siswa SMA ditinjau dari gaya kognitif reflektif dan impulsif, maka peneliti memberikan saran-saran sebagai berikut.

1. Disarankan bagi peneliti lain yang melakukan penelitian sejenis dapat menggunakan materi lain.

2. Dilakukan penelitian lebih lanjut tentang cara berpikir relasional siswa ditinjau dengan gaya kognitif yang berbeda.

3. Dilakukan penelitian lebih lanjut tentang kemungkinan kedua siswa kembali ke tahap sebelumnya. 


\section{DAFTAR PUSTAKA}

A. Tatak Handaya Kurniawan, M. Andy Rudhito. 2016. Kemampuan Berpikir Relasional Siswa dalam Mengerjakan Soal Kontekstual dengan Pendekatan Realistik Pada Topik Fungsi Linear.

Ahmadi, A dan Supriyono, W. 2013. Psikologi Belajar. Jakarta: Rineka Cipta.

Anggara, S. 2010. Perilaku Organisasi. Bandung: CV Pustaka Setia.

Bahri, A. S., Lukito, A., \& Masriyah, M. (2019). Students' Relational Thinking in Solving Word Problem Based Cognitive Style. International Journal of Trends in Mathematics Education Research, 2(1), 37.

Baiduri. 2011. Profil Berpikir Relasional Siswa SD Menyelesaikan Masalah Ditinjau dari Kemampuan Matematika dan Gender. Disertasi tidak dipublikasikan. UNESA Surabaya.

Doumas, L.A.A., and Hummel, J.E. 2005. Approaches to Modeling Human Mental Representations: What Works, What Doesn't, and Why. Cambridge: University Press.

Empson, Susan B., Levi, L., \& Carpenter, Thomas P. 2011. The Algebraic Nature of Fractions: Developing Relational Thinking in Elementary School. ZDM-International Reviews on Mathematical Education

Hejny, M., Jirotkova, D. \& Kratochvilova, D. 2006. Early Conceptual Thinking. Proceedings 30th Conferences of The International Group for The Psychology of Mathematics Education, Vol. 33, pp. 289-296. Prague: PME.

Kafiar, Elisabeth dkk. 2015. Proses Berpikir Siswa SMA Dalam Memecahkan Masalah Matematika Pada Materi SPLTV Ditinjau Dari Gaya Kognitif Field Independent Dan Field Dependent: Jurnal Ilmiah Matematika Dan Pembelajarannya.

Molina, M., Castro, E., \& Ambrose, R. 2005. Enriching arithmetic learning by promoting relational thinking. International Journal of Learning, 12(5), 265-270.

Moursund, D. 2016. Learning Problem-solving Strategies by Using Games: A Guide for Educators and Parents. Eugene, OR: Information Age Education.

Nasution. 2008. Berbagai Pendekatan dalam Proses Belajar dan Mengajar. Jakarta: PT Bumi Aksara.
National Council of Teacher of Mathematics (NCTM). 1989. Curriculum and Evaluation Standards for School Mathematics. Reston, VA: Authur

Nimtrakul, Bongkoch., Sangaroon, K., \& Inprasitha, M. 2014. Using Relational Thinking Strategies to Establish the Relationship between Conceptual and Procedural Knowledge in Mathematics Problem Solving Classrooms. HRD Journal Vol. 5.

Polya, G. 2004. How to Solve It. New Jersey: Princeton University.

Sari, Defvi Mirna Liyan. 2016. Berpikir Relasional Siswa SMP dalam Menyelesaikan Masalah Perbandingan Ditinjau dari Kemampuan Matematika. Tesis tidak dipublikasikan.

Shadiq, F. 2003. Penalaran, Pemecahan Masalah dan Komunikasi dalam Pembelajaran Matematika. Paket Pembinaan Penataran (PPP). Yogyakarta: PPPG Matematika.

Sintha Sih Dewanti, S.Pd.Si., M.Pd.Si. 2011 Mengembangkan Kemampuan Berpikir Kritis Mahasiswa Pendidikan Matematika Sebagai Calon Pendidik Karakter Bangsa Melalui Pemecahan Masalah. Surakarta.

Siswono, T. 2008. Model Pembelajaran Matematika Berbasis Pengajuan dan Pemecahan Masalah untuk Meningkatkan. Kemampuan Berpikir Kreatif. Surabaya: UNESA University Press.

Stephens, M., and Ribeiro, A. 2012. Working Towards Algebra: The Importance of Relational Thinking. Revista Latinoamerica de Invertigation en Matematica Ecuatina 15 (3), 1-31.

Tafrilyanto, C. F. 2016. Profil Berpikir Relasional Siswa SMA dalam Pemecahan Masalah Matematika Ditinjau dari Gaya Kognitif Field Dependent. $\Sigma$ IGMA, Vol 2, No 1.

Warli. 2010. Kreatifitas Siswa SMP yang Bergaya Kognitif Reflektif atau Impulsif dalam Memecahkan Masalah Geometri. Disertasi tidak diterbitkan. Surabaya: Pasca Sarjana Unesa.

Widjajanti, D. 2011. Mengembangkan Kecakapan Matematis Mahasiswa Calon Guru Matematika melalui Strategi Perkuliahan Kolaboratif Berbasis Masalah. Universitas Negeri Yogyakarta.

Peraturan Menteri Pendidikan Nasional Republik Indonesia No. 58 tahun 2014. 